\section{Seed Maturity and Desiccation Affect Carbohydrate Composition and Leachate Conductivity in shrunken-2 Sweet Corn}

\author{
Alicia M. Borowski ${ }^{1}$, Vincent A. Fritz ${ }^{2}$, and Luther Waters, Jr. ${ }^{3}$ \\ Department of Horticultural Science, University of Minnesota, St. Paul, \\ MN 55108
}

Additional index words. Zea mays, sucrose, raffinose, membranes

\begin{abstract}
This study was conducted to determine if changes in the raffinose : sucrose ratio in embryos of shrunken-2 sweet corn (Zea mays L.) hybrids were related to differences in seed leachate conductivity between two hybrids harvested at four maturities and artificially dried to $0.10 \mathrm{~g} \mathrm{H}_{2} \mathrm{O} / \mathrm{g}$ fresh weight. The ratio of raffinose : sucrose differed for ' $\mathrm{Crisp}$ N' Sweet 710' (CNS) and 'How Sweet It Is' (HSII). The mass ratio of raffinose : sucrose in CNS was >0.3 in seed harvested between 0.44 to $0.64 \mathrm{~g} \mathrm{H}_{2} \mathrm{O} / \mathrm{g}$ fresh weight and increased as seed dried from the initial harvest moisture to $0.10 \mathrm{~g} \mathrm{H}_{2} \mathrm{O} / \mathrm{g}$ fresh weight. Raffinose : sucrose ratios of HSII were $<0.3$ at all harvests between 0.55 to $0.72 \mathrm{~g} \mathrm{H}_{2} \mathrm{O} / \mathrm{g}$ fresh weight, but changes during desiccation were not as pronounced. Leachate conductivity of whole seeds of CNS and HSII decreased as seeds were harvested at progressively lower moisture contents. We suggest that a higher raffinose : sucrose ratio may be indicative of increased seed vigor in shrunken-2 hybrids.
\end{abstract}

Sweet corn has the third highest acreage, production, and cash value of all processed vegetable crops in the United States (Lorenz and Maynard, 1988). Producers are interested in shrunken-2 $\left(s h_{2}\right)$ hybrids because of their extra sweetness and extended postharvest quality retention. However, the erratic emergence and poor seedling vigor of these hybrids has resulted in limited acceptance by an industry that depends on uniformity of plant stands and subsequent maturity.

Seed vigor and field emergence of sweet corn seed has been correlated with the conductivity of seed leachates (Tracy and Juvik, 1988; Waters and Blanchette, 1983). Shrunken-2 sweet corn hybrids leak more solutes during imbibition than standard $(\mathrm{su})$ sweet corn genotypes (Schmidt and Tracy, 1988; Wann, 1986). Leakage of solutes from seeds during imbibition has been associated with membrane damage (Powell, 1988). Simon and Raja Harun (1972) hypothesized that semipermeable membranes (tonoplast and plasma membrane) of pea (Pisum sativum L.) embryos lose their integrity during maturation drying and are incapable of acting as retentive barriers during imbibition.

Although the lipid bilayer of the plasma

Received for publication 31 Mar. 1995. Accepted for publication 14 Aug. 1995. Minnesota Agricultural Experiment Station Journal Series no. 18,832. The cost of publishing this paper was defrayed in part by the payment of page charges. Under postal regulations, this paper therefore must be hereby marked advertisement solely to indicate this fact.

${ }^{1}$ Former Graduate Research Assistant. Current address: Goldsmith Seeds, P.O. Box 1349, Gilroy, CA 95021.

${ }^{2}$ Associate Professor. Southern Experiment Station, 35838 120th St.,Waseca, MN 56093.

${ }^{3}$ Current address: Dept. of Horticulture and Crop Science, The Ohio State Univ., Columbus, $\mathrm{OH}$ 43210. membrane is highly dependent on the organizational forces of water, it continues to be maintained during dehydration (Luzzati, 1968), while the physical properties of phospholipids are altered, i.e., some may be in gel phase when dry at ambient temperatures (Crowe and Crowe, 1986a). As membranes rehydrate at a particular temperature, some phospholipids undergo a phase transition to the liquidcrystalline state, while others remain in the gel state. This hydration-induced phase transition in the bilayer may be responsible for the initial leakage during imbibition (Crowe and Crowe, 1986b).

Seeds may have the ability to survive desiccation because they possess a mechanism that protects cellular membranes (Leopold and Vertucci, 1986). Sucrose, a prevalent carbohydrate in seeds, may serve as a protectant of membranes during desiccation by altering the physical properties of membrane phospholipids such that they retain characteristics of a hydrated lipid even in a dry seed (Crowe and Crowe, 1986a). Pure sucrose tends to crystallize at low moisture contents, but when present in a 1:0.3 mass ratio with raffinose, an abundant oligosaccharide in many seeds, crystallization is inhibited (Caffrey et al., 1988). Using phospholipid model membranes, Caffrey et al. (1988) demonstrated reduced leakage in artificial vesicles that contained sucrose and raffinose than in vesicles containing sucrose alone.

The objectives of this research were to 1) determine if there are differences in the amounts of sucrose and raffinose in embryos of two $s h_{2}$ sweet corn hybrids that differ in vigor (Crookham Co., Caldwell, Idaho; personal communication), 2) measure the changes in sucrose and raffinose contents of embryos during desiccation, and 3 ) determine if the ratio of raffinose : sucrose in these embryos is correlated with membrane integrity in seeds (as measured by solute leakage).
Seed production. Parental inbreds of two commercial $s h_{2}$ hybrids, 'Crisp N' Sweet 710' (CNS) and 'How Sweet It Is' (HSII) (Crookham Co.), were planted in early May at the Southern Experiment Station, Waseca, Minn., on a Webster clay loam (Typic Haplaquolls, fine loamy, mixed mesic) with a $\mathrm{pH}$ of 7.0 and $\mathrm{P}$ and $\mathrm{K}$ levels of 81 and $362 \mathrm{mg} \cdot \mathrm{kg}^{-1}$, respectively. Urea was broadcast at $137 \mathrm{~kg} \mathrm{~N} / \mathrm{ha}$ and incorporated before planting. Plantings were spaced at appropriate intervals to ensure pollen shed and silking would coincide to allow hand pollinations to be conducted over 5 days.

The herbicides 2-chloro-2-6-diethyl- $N$ (methoxymethyl) acetanilide (alachlor) and 2[(4-chloro-6-(ethylamino)-s-triazin-2-yl) amino]-2-methylpropionitrile (cyanazine) were broadcast preemergence at 2.8 and 2.3 $\mathrm{kg} \cdot \mathrm{ha}^{-1}$, respectively. 1-Napthyl $N$-methyl-carbamate (carbaryl) and ethylene bisthiocarbamate with manganese and zinc (mancozeb) were sprayed as needed for insect and disease control at 1.4 and $2.3 \mathrm{~kg} \cdot \mathrm{ha}^{-1}$, respectively.

Seed moisture levels were monitored two to three times per week during the season with an automatic volatility computer, which is comprised of a microwave drying oven, electronic balance, and microprocessor (Borowski and Fritz, 1990). Four harvests of CNS were taken at moisture levels of $\approx 0.71,0.64,0.54$, and $0.44 \mathrm{~g} \mathrm{H}_{2} \mathrm{O} / \mathrm{g}$ fresh weight, which correspond to 43, 52, 62, and 69 days after pollination (DAP), respectively. Only three harvests of HSII were made, at moisture levels of 0.72 , 0.63 , and $0.55 \mathrm{~g} \mathrm{H}_{2} \mathrm{O} / \mathrm{g}$ fresh weight $(44,57$, and 63 DAP, respectively), because of severe ear rot later in the season.

Embryos were extracted at three stages of seed desiccation: 1) before artificial drying, 2) midway through artificial drying, and 3) after drying to $0.10 \mathrm{~g} \mathrm{H}_{2} \mathrm{O} / \mathrm{g}$ fresh weight. At each harvest, 40 ears, each within a single pollination date, were hand-picked and husked at random. To obtain embryo samples at the initial harvest moisture, five randomly selected ears were placed in a sealed plastic bag and refrigerated at $4 \mathrm{C}$. Twelve seeds from each ear were excised at cob level from the center $10 \mathrm{~cm}$ of the ear followed by extraction and immediate freezing of the embryo with dry ice. The remaining 35 ears were dried in a closed-system, forced-air dryer at 32C (Fritz et al., 1990). The embryo extraction procedure was repeated as seeds dried to Stages 2 and 3 . The frozen embryos were stored at $-30 \mathrm{C}$ and freeze-dried within 2 to 4 weeks.

Carbohydrate analysis. Sucrose and raffinose contents were determined according to Hanft et al. (1986). Several procedural modifications were necessary due to the nature of the embryo tissue. Three 75-mg samples of powdered embryo tissue were extracted in 5 $\mathrm{ml}$ of distilled water at $60 \mathrm{C}$ for $2 \mathrm{~h}$ and centrifuged at $2000 \times g$ for $30 \mathrm{~min}$. Samples were filtered through nylon PTFE filters $(0.45-\mu \mathrm{m}$ pores; Chromtech, Apple Valley, Minn.) before passage through C-18 Sep-Pak solid phase extraction cartridges (Waters Associates, Milford, Mass.). Samples were evaporated to 
dryness overnight at $25 \mathrm{C}$. The dried residue was resuspended in $0.5 \mathrm{ml}$ deionized water followed by addition of $1.5 \mathrm{ml}$ acetonitrile. Samples were filtered again through $0.45-\mu \mathrm{m}$ filters before injection into a Waters highperformance liquid chromatography (HPLC) system with a carbohydrate analysis column (Waters Associates). The mobile phase was $75 \%(\mathrm{v} / \mathrm{v})$ acetonitrile at $2.0 \mathrm{ml} \cdot \mathrm{min}^{-1}$. Sucrose and raffinose were quantified using external standards. Sample injection volume was 200 $\mu$ l. Sugars were detected with a refractive index detector (model ERC-77510; Erma Optical Works, Tokyo).

Seed leachate conductivity. Leachate conductivity of whole seeds at the final moisture level of $0.10 \mathrm{~g} \mathrm{H}_{2} \mathrm{O} / \mathrm{g}$ fresh weight was measured with the ASA-610 Electronic Seed Analyzer (Neogen Food Tech. Corp., Lansing, Mich.). Samples of 100 seeds were soaked in distilled water in imbibing trays and stored in a germination chamber set at $25 \mathrm{C}$ for $24 \mathrm{~h}$ before testing.

Data analyses. Sucrose and raffinose quantities and seed leachate conductivity were subjected to general linear model analysis (SAS Institute, Cary, N.C.).

\section{Results}

Carbohydrate content of embryos. In CNS, as the seed moisture level at harvest decreased, sucrose levels decreased and raffinose levels increased (Table 1). For HSII, the trend for sucrose was similar to CNS, but raffinose levels tended to decrease as harvest moisture decreased.

As seed of CNS was artificially dried from the initial harvest moisture to the final seed moisture of $0.10 \mathrm{~g} \mathrm{H}_{2} \mathrm{O} / \mathrm{g}$ fresh weight, sucrose and raffinose levels increased (Table 2). Sucrose levels of HSII also increased as seed was dried from the initial harvest moisture to 0.10 $\mathrm{g}_{2} \mathrm{O} / \mathrm{g}$ fresh weight, but raffinose levels increased from Stage 1 (initial moisture) to Stage 2 (mid-drying), then mostly decreased between Stage 2 (mid-drying) and Stage 3 (final moisture).

The inconsistencies in the HSII data may be due to pathogen infection. Ears at the first harvest $\left(0.72 \mathrm{~g} \mathrm{H}_{2} \mathrm{O} / \mathrm{g}\right.$ fresh weight) were not visibly infected. As seed moisture dropped below $0.65 \mathrm{~g} \mathrm{H}_{2} \mathrm{O} / \mathrm{g}$ fresh weight at harvest, the number of infected ears greatly increased. We tried to select ears of the highest quality for embryo samples taken at harvest moistures of 0.63 and $0.55 \mathrm{~g} \mathrm{H}_{2} \mathrm{O} / \mathrm{g}$ fresh weight; however due to the limited supply of noninfected ears, samples taken for moisture determination and embryo samples may not have been representative of the seed lot

Mass ratio of raffinose: sucrose. The mass ratio of raffinose : sucrose increased in embryos of CNS as seed matured and dried naturally (Fig. 1). The ratio between raffinose and sucrose was lowest at $0.71 \mathrm{~g} \mathrm{H}_{2} \mathrm{O} / \mathrm{g}$ fresh weight and rose above the 0.3 "ideal ratio" when harvested at $0.64,0.54$, and $0.44 \mathrm{~g} \mathrm{H}_{2} \mathrm{O}$ / $\mathrm{g}$ fresh weight. How a raffinose : sucrose ratio of $>0.3$ will affect membrane performance is unknown, since Caffrey et al. (1988) did not

Table 1. Effect of harvest on sucrose, raffinose, and seed leachate conductivity of 'Crisp N' Sweet 710' (CNS) and 'How Sweet It Is' (HSII) at 10 to $12 \mathrm{~g} \mathrm{H}_{2} \mathrm{O} / \mathrm{g}$ fresh weight from four and three harvests, respectively.

\begin{tabular}{lccccc}
\hline \hline Cultivar & $\mathrm{DAP}^{z}$ & $\begin{array}{c}\text { Seed } \\
\text { moisture } \\
\text { at harvest } \\
\left(\mathrm{g} \mathrm{H}_{2} \mathrm{O} / \mathrm{g} \text { fresh wt }\right)\end{array}$ & $\begin{array}{c}\text { Sucrose } \\
(\mathrm{mg} / \mathrm{g} \text { dry wt })\end{array}$ & $\begin{array}{c}\text { Raffinose } \\
\text { Conductivity } \\
(\mu \mathrm{mps})\end{array}$ \\
\hline CNS & 43 & 0.71 & 57.6 & 14.2 & 71.3 \\
& 52 & 0.64 & 47.4 & 16.9 & 43.6 \\
& 62 & 0.54 & 44.3 & 17.8 & 30.4 \\
HSII & 69 & 0.44 & 40.2 & 18.3 & 31.9 \\
& 44 & 0.72 & 63.6 & 15.3 & 60.7 \\
& 57 & 0.63 & 56.7 & 11.3 & 63.1 \\
\hline
\end{tabular}

${ }^{2 \mathrm{DAP}}=$ days after pollination.

Table 2. Effect of three stages of desiccation within individual harvests on levels of sucrose and raffinose in embryos of 'Crisp N' Sweet 710' (CNS) and 'How Sweet It Is' (HSII).

\begin{tabular}{|c|c|c|c|c|c|c|}
\hline \multirow{3}{*}{$\mathrm{DAP}^{\mathrm{z}}$} & \multirow{2}{*}{$\begin{array}{c}\text { Seed moisture } \\
\text { at harvest } \\
\text { ( } \mathrm{g} \mathrm{H}_{2} \mathrm{O} / \mathrm{g} \text { fresh wt) }\end{array}$} & \multirow[b]{2}{*}{$\begin{array}{c}\text { Stage of } \\
\text { desiccation }\end{array}$} & \multicolumn{2}{|c|}{ CNS } & \multicolumn{2}{|c|}{ HSII } \\
\hline & & & $\begin{array}{r}\begin{array}{l}\text { Sucrose } \\
(\mathrm{mg}\end{array}\end{array}$ & (mg/g dry wt) & \multicolumn{2}{|c|}{ (mg/g dry wt) } \\
\hline & & 1 & 45.6 & 12.8 & 46.6 & 13.1 \\
\hline 43 & $0.71, \mathrm{CNS}$ & 2 & 59.1 & 14.5 & 65.1 & 18.1 \\
\hline \multirow[t]{2}{*}{44} & 0.72, HSII & 3 & 68.1 & 15.4 & 76.1 & 14.9 \\
\hline & & 1 & 38.4 & 14.5 & 49.7 & 9.8 \\
\hline 52 & $0.64, \mathrm{CNS}$ & 2 & 48.7 & 18.2 & 63.1 & 12.5 \\
\hline \multirow[t]{2}{*}{57} & 0.63 , HSII & 3 & 55.1 & 17.9 & 57.2 & 11.5 \\
\hline & & 1 & 38.1 & 17.3 & 43.3 & 10.8 \\
\hline 62 & $0.54, \mathrm{CNS}$ & 2 & 46.5 & 17.3 & 47.5 & 12.2 \\
\hline \multirow[t]{3}{*}{63} & 0.55, HSII & 3 & 48.4 & 18.7 & 51.4 & 13.8 \\
\hline & & 1 & 26.7 & 13.9 & --- & --- \\
\hline & & 2 & 43.8 & 19.6 & --- & --- \\
\hline 69 & $0.44, \mathrm{CNS}$ & 3 & 50.0 & 21.3 & --- & --- \\
\hline
\end{tabular}

${ }^{\mathrm{Q}}$ Days after pollination.

${ }^{\mathrm{y}} 1$ = initial harvest moisture; 2 = midway through drying; 3 = final seed moisture of 10 to $12 \mathrm{~g} \mathrm{H}_{2} \mathrm{O} / \mathrm{g}$ fresh weight.

examine higher mass ratios. In contrast, the mass ratio of raffinose : sucrose in HSII embryos from harvests at $0.72,0.63$, and $0.55 \mathrm{~g}$ $\mathrm{H}_{2} \mathrm{O} / \mathrm{g}$ fresh weight was never more than 0.3 and did not increase as observed with CNS (Fig. 1).

As seeds dried from the initial harvest moisture to the final seed moisture, the raffinose : sucrose ratio decreased in CNS embryos at all harvests; however, the rate of decrease was only significant in seed harvested at 0.71 $\mathrm{g} \mathrm{H}_{2} \mathrm{O} / \mathrm{g}$ fresh weight (Fig. 2A). In general, the ratio was highest at the initial harvest moisture and decreased as seeds dried to $0.10 \mathrm{~g} \mathrm{H}_{2} \mathrm{O} / \mathrm{g}$ fresh weight. In HSII embryos, the changes in raffinose : sucrose ratios as seeds dried were not as pronounced as in CNS; however, seed harvested at $0.55 \mathrm{~g} \mathrm{H}_{2} \mathrm{O} / \mathrm{g}$ fresh weight showed a significant increase in the raffinose : sucrose ratio as seed dried (Fig. 2B).

Seed leachate conductivity. The conductivity of leachates from whole seeds of CNS and HSII decreased as seeds matured from 0.71 and $0.72 \mathrm{~g} \mathrm{H}_{2} \mathrm{O} / \mathrm{g}$ fresh weight to 0.44 and $0.55 \mathrm{~g} \mathrm{H}_{2} \mathrm{O} / \mathrm{g}$ fresh weight at harvest, respectively (Table 1). As leachate conductivity decreased, raffinose : sucrose ratios increased (Fig. 3).

\section{Discussion}

The role of sucrose and raffinose in membrane stabilization during desiccation of seeds has not received adequate attention. Schleppi and Burris (1989) examined carbohydrate lev- els in embryos of sugary and $s h_{2}$ sweet corn seeds that had been "preconditioned" during drying (seeds were exposed to $35 \mathrm{C}$ for 0 to 48 $\mathrm{h}$ before completion of drying at 50C). They observed a "preconditioning" effect in the $s h_{2}$ hybrid only. An improved germination rate and decreased leachate conductivity corresponded to an accumulation of raffinose and a glucose-xylose oligosaccharide in the embryos. In a preconditioning drying experiment with field corn, Chen and Burris (1990) suggest the changes in soluble sugar composition, especially the ratio of raffinose : sucrose, rather than the absolute content of sugars, was highly correlated with membrane stability during high-temperature drying.

Our data demonstrate how the raffinose : sucrose ratio varies between hybrids and changes as seed matures and dries. Within the $s h_{2}$ genotype, there is a great deal of variability in seed vigor. CNS had lower seed leachate conductivity and a higher raffinose : sucrose mass ratio than HSII at most harvest moistures. We suggest that a higher raffinose : sucrose ratio may indicate increased seed vigor in $s h_{2}$ hybrids and that this ratio might be a useful trait in breeding programs. Examination of the carbohydrate ratio of embryos of other $s h_{2}$ hybrids would be necessary to provide additional support to this hypothesis.

Changes in the raffinose: sucrose ratio also could have implications on the moisture level at which seed is harvested and on how seed is dried, handled, and packaged. Most $s h_{2}$ seed is harvested between 0.35 to $0.45 \mathrm{~g} \mathrm{H}_{2} \mathrm{O} / \mathrm{g}$ fresh 


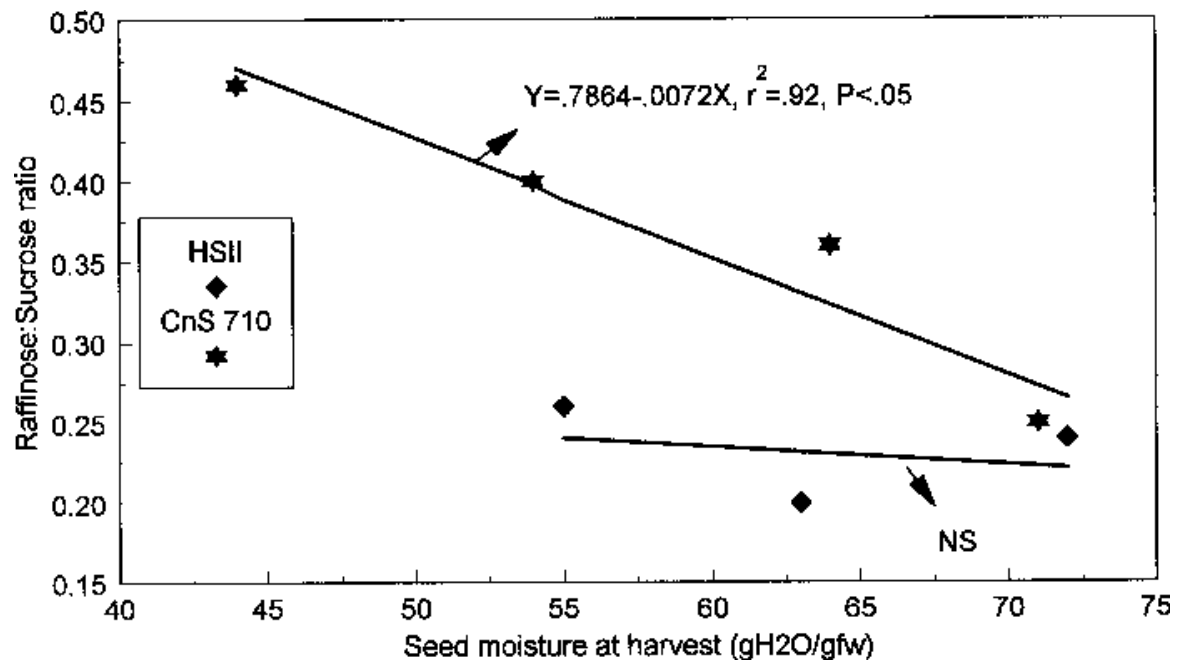

Fig. 1. Relationship between seed maturity at harvest and embryo raffinose : sucrose ratios in embryos of 'Crisp N' Sweet 710' (CNS) and 'How Sweet It Is' (HSII).
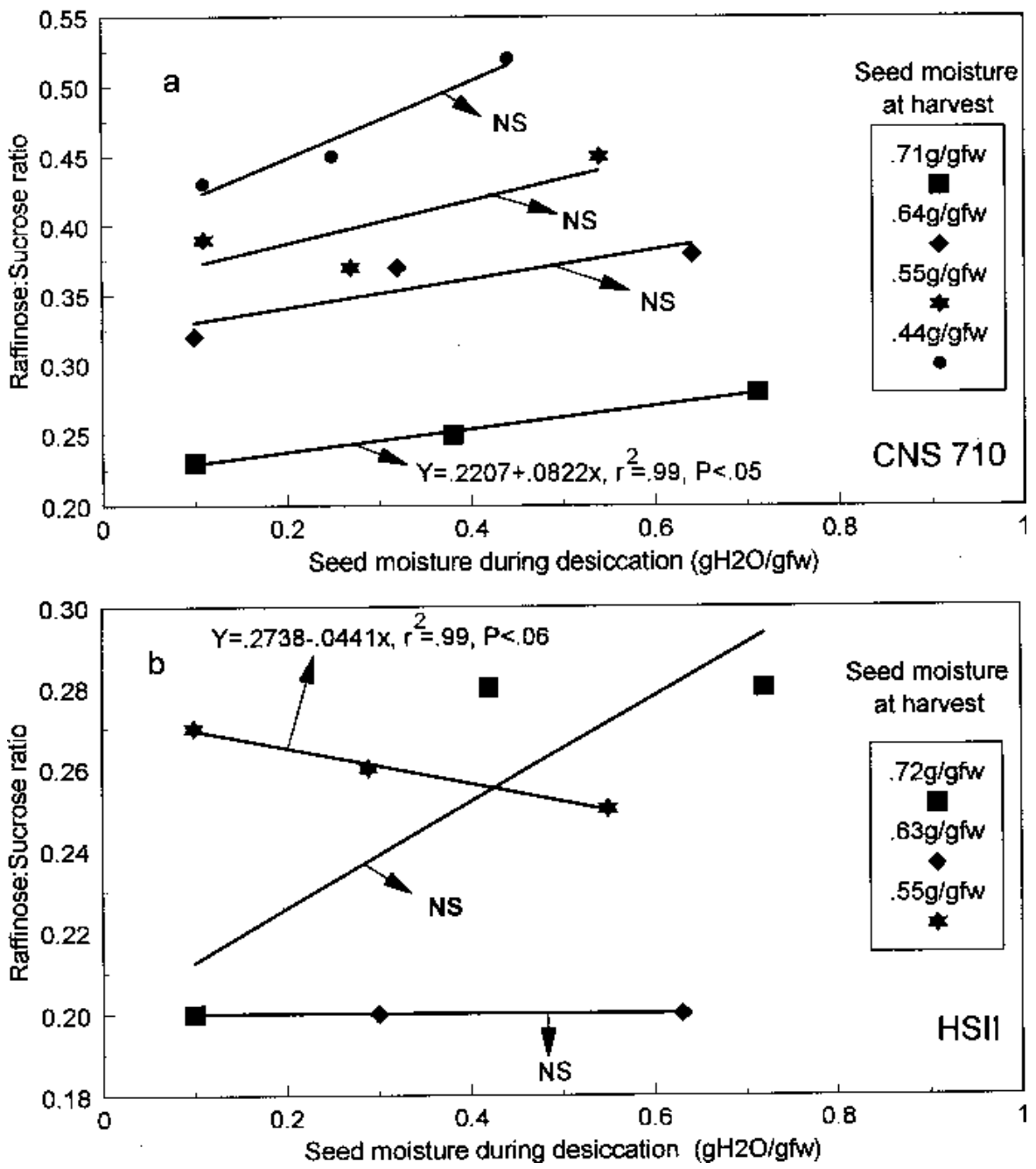

Fig. 2. Effects of desiccation on raffinose : sucrose ratios in embryos of (A) 'Crisp N' Sweet 710' and (B) 'How Sweet It Is'.

weight. Seed of CNS harvested at higher moisture levels, 0.50 to $0.65 \mathrm{~g} \mathrm{H}_{2} \mathrm{O} / \mathrm{g}$ fresh weight, has performed well in standard and cold germination tests (Borowski et al., 1991). The highest mass ratios of raffinose to sucrose and seed leachate conductivity measurements ex- modified to handle the high-moisture seed.

The majority of seed of most orthodox crop species is dried to 0.10 to $0.15 \mathrm{~g} \mathrm{H}_{2} \mathrm{O} / \mathrm{g}$ fresh weight since metabolic activities are virtually arrested, pathogen activity is minimal, and the seed is able to be stored (Bewley and Black, 1985). However, as seed of CNS was dried to $0.10 \mathrm{~g} \mathrm{H}_{2} \mathrm{O} / \mathrm{g}$ fresh weight, the raffinose : sucrose ratio decreased. To further determine whether this decrease in the mass ratio during drying is related to seed vigor, germination percentages and leachate conductivity need to be tested at all stages of seed desiccation, not just at the final seed moisture. If additional evidence showed a correlation between the raffinose : sucrose ratio and seed vigor, then changes in the drying and storage practices of seeds might be implemented.

There are several factors that contribute to seed vigor. They include genetic potential, environmental conditions at time of seed formation, date of harvest, maturity at harvest, mechanical damage, drying problems, storage temperature and relative humidity, duration of storage, and insects and diseases (Amaral, 1981). Pericarp integrity is also important since it protects the seed from pathogen attack and regulates water into and out of the seed; however, pericarp thickness does not appear to be correlated to field emergence in $s h_{2}$ sweet corn (Tracy and Juvik, 1989). We suggest that the raffinose : sucrose ratio within the embryo may play a role in relative field performance through membrane stabilization and repair.

First, we need to establish more definitively that vigor in $s h_{2}$ hybrids is significantly related to membrane stabilization. The greatest changes in membranes occur during maturation, drying, and imbibition (Abdul-Baki, 1980), and so we must determine at which stage membranes are more likely to sustain damage. To modify current seed drying and processing procedures would be expensive. However, conditioning seed before planting by moisturization (Bennett and Waters, 1987) or solid matrix priming (Taylor et al., 1988) is relatively easy, inexpensive, and improves germination. Basra et al. (1988) demonstrated osmotic priming of maize seeds with polyethylene glycol or potassium salts accelerated germination at 10C. They hypothesized that an increase in diphosphatidylglycerol may be indicative of enhanced internal organization of mitochondrial membranes.

Research on presowing treatments might provide immediate results leading to the improvement of seed vigor and stand establishment of shrunken-2 hybrids, but understanding membrane function and dynamics during seed development and maturation will provide a fundamental understanding of the role membranes play in seed vigor.

\section{Literature Cited}

Abdul-Baki, A.A. 1980. Biochemical aspects of seed vigor. HortScience 15:764-788.

Amaral, A. 1981. Several aspects of seed vigor. Lavoura Arrozeira 34:58-63.

Basra, A.S., S. Bedi, and C.P. Malik. 1988. Accelerated germination of maize seeds under chilling stress by osmotic priming and associated 


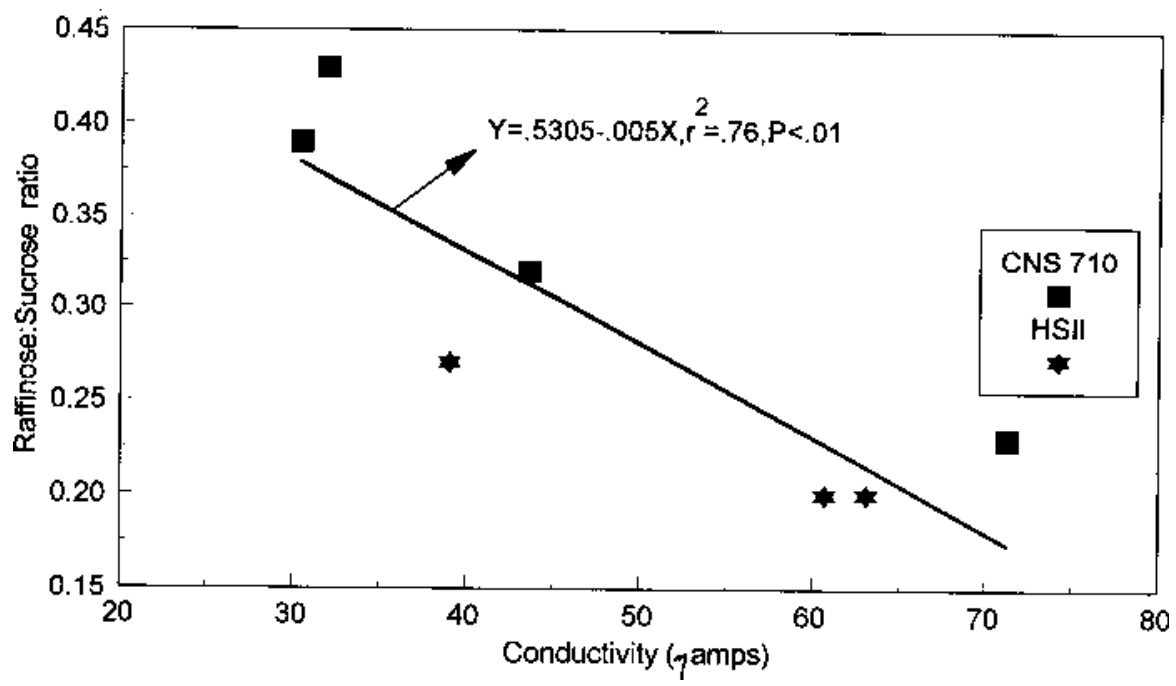

Fig. 3. Relationship between seed leachate conductivity and embryo raffinose : sucrose ratio averaged across both shrunken-2 sweet corn hybrids.

changes in embryo phospholipids. Ann. Bot. 61:635-639.

Bennett, M.A. and L. Waters, Jr. 1987. Germination and emergence of high-sugar sweet corn is improved by presowing hydration of seed. HortScience 22:236-238.

Bewley, J.D. and M. Black. 1985. Seeds. Physiology of development and germination. Plenum Press, New York.

Borowski, A.M. and V.A. Fritz. 1990. Comparison of moisture determination techniques over a range of sweet corn seed maturities. HortScience $25: 361$.

Borowski, A.M., V.A. Fritz, and L. Waters, Jr. 1991. Seed maturity influences germination and vigor of two shrunken-2 sweet corn hybrids. J. Amer. Soc. Hort. Sci. 116:401-404.

Caffrey, M., V. Fonseca, and A.C. Leopold. 1988 Lipid sugar interactions. Relevance to anhydrous biology. Plant Physiol. 86:754-758.
Chen, Y. and J.S. Burris. 1990. Role of carbohydrates in desiccation tolerance and membrane behavior in maturing maize seed. Crop Sci. 30:971-975.

Crowe, J.H. and L.M. Crowe. 1986a. Stabilization of membranes in anhydrobiotic organisms, p. 188-209. In: A.C. Leopold (ed.). Membranes, metabolism, and dry organisms. Comstock Publ. Assoc., Ithaca, N.Y.

Crowe, J.H. and L.M. Crowe. 1986b. Hydrationdependent phase transitions and permeability properties of biological membranes, p. 210 231. In: A.C. Leopold (ed.). Membranes, metabolism, and dry organisms. Comstock Publ. Assoc., Ithaca, N.Y.

Fritz, V.A., H.A. Cloud, R.F. Deef, and A.M Borowski. 1990. A versatile heat pump seed dryer. HortScience 25:977-978.

Hanft, J.M., R.J. Jones, and A.B. Stumme. 1986. Dry matter accumulation and carbohydrate con- centration patterns of field-grown and in vitro cultured maize kernels from the tip and middle ear positions. Crop Sci. 26:568-572.

Leopold, A.C. and C.W. Vertucci. 1986. Physical attributes of desiccated seeds, p. 22-34. In: A.C. Leopold (ed.). Membranes, metabolism, and dry organisms. Comstock Publ. Assoc., Ithaca, N.Y.

Lorenz, O.A. and D.N. Maynard. 1988. Knott's handbook for vegetable growers. Wiley, New York.

Luzzati, V. 1968. X-ray diffraction studies of lipidwater systems, p. 71-123. In: D. Chapman (ed.). Biological membranes. Physical fact and function. Academic, New York.

Powell, A.A. 1988. Seed vigour and field establishment, p. 29-61. In: S. Matthews (ed.). Advances in research and technology of seeds. Part 11. Pudoc (Wageningen), The Netherlands.

Schleppi, P. and J.S. Burris. 1989. Sweet corn as a model system in which to study corn seed maturation and membrane stabilization. Iowa Seed Sci. 11(2):9-12.

Schmidt, D.H. and W.F. Tracy. 1988. Endosperm type, inbred background, and leakage of seed electrolytes during imbibition in sweet corn. $\mathbf{J}$. Amer. Soc. Hort. Sci. 113:269-272.

Simon, E.W. and R.M. Raja Harun. 1972. Leakage during seed imbibition. J. Expt. Bot. 23:10761085.

Taylor, A.G., D.E. Klein, and T.H. Whitlow. 1988. SMP: Solid matrix priming of seeds. Scientia Hort. 37:1-11.

Tracy, W.F. and J.A. Juvik. 1988. Electrolyte leakage and seed quality in a shrunken- 2 maize selected for improved field emergence. HortScience 23:391-392

Tracy, W.F. and J.A. Juvik. 1989. Pericarp thickness of a $s h_{2}$ population of maize selected for improved field emergence. Crop Sci. 29:72-74.

Wann, E.V. 1986. Leaching of metabolites during imbibition of sweet corn seed of different endosperm genotypes. Crop Sci. 26:731-733.

Waters, L., Jr., and B.L. Blanchette. 1983. Prediction of sweet corn field emergence by conductivity and cold tests. J. Amer. Soc. Hort. Sci. 108:778-781. 